\title{
Water Harvesting and Conservation under Cold Desert Condition of Ladakh (J\&K): Constraints and Strategies
}

\author{
Phuntsog Tundup ${ }^{1}$, M. A. Wani ${ }^{1}$, Sonam Dawa ${ }^{2}$, Shabber Hussain ${ }^{3}$ and Jigmat Laskit ${ }^{4}$ \\ ${ }^{1}$ Division of Soil Science, SKUAST-K, Shalimar-190025, India \\ ${ }^{2}$ Division of FMAP, SKUAST-K, Shalimar-190025, India \\ ${ }^{3}$ Division of Fruit Science, SKUAST-K, Shalimar-190025, India \\ ${ }^{4}$ KVK, Nyoma, SKUAST-K, Shalimar-190025, India \\ *Corresponding author
}

\section{A B S T R A C T}

Keywords

Leh, Zing,

Artificial glacier,

Seabuckthorn,

Cold arid.

Article Info

Accepted:

24 January 2017

Available Online:

10 February 2017
Leh district is situated between $31-36^{\circ} \mathrm{N}$ latitude and $76-80^{\circ} \mathrm{E}$ longitude with an altitude ranging from 2500 to $6000 \mathrm{~m}$ above mean sea level. Leh is the largest district in the country with an area of $45,100 \mathrm{Km}^{2}$. Agriculture is the main occupation of the rural people of the district. It was observed that traditional recharge structure practiced in Ladakh was locally called as Zing. Snow is an important source of water in cold arid regions, and the moisture from it is much more efficiently stored in soil than from rain. Artificial glaciers have been innovated. Retaining tall standing stubble after harvest or alternating strips of tall and short stubble. Re vegetation with seabuck thorn could be successfully used on large scale.

\section{Introduction}

Without conservation measures on extremely fragile terrain, as in the cold-desert condition of Ladakh region that has an area of 7.0 mha, (Goyal, 2010), the threat of land degradation and loss of fertile soil will exacerbate. Water harvesting and moisture conservation should evolve together for a sustainable mountain environment. Water harvesting pertains to the process of collecting and storing water from the specified areas. The water can be stored successfully in tanks, reservoirs and in the soils. The water is diverted from the watershed to the fields/crops. This practice however, was popular in many countries of the world particularly in the desert regions.
These old systems of water storing are the pavements of modern water harvesting systems.

\section{Materials and Methods}

The Ladakh region is one of the most elevated (2900 $\mathrm{m}$ to $5900 \mathrm{~m}$ asl) and coldest region ($30{ }^{0} \mathrm{C}$ to $-70{ }^{0} \mathrm{C}$ ) of the earth and lies between $31^{\circ} 44^{\prime} 57^{\prime \prime}$ to $32^{0} 59^{\prime} 57^{\prime \prime} \mathrm{N}$ latitude and $76^{\circ}$ $46^{\prime} 29$ ' ' to $80^{\circ} 41^{\prime}$ 34' $\mathrm{\prime}$ longitude. There watershed areas in the cold arid region are namely, Skurbuchan, Khaltsi, Domkhar, Gonpa, stok, Matho in Leh district and most villages like Hardass, Sanjaq, Batalik, 
Trespon and Garkon in Kargil district located near L.O.C which remains land locked for more than six months in a year. The villages falls in Leh district were located around the famous river Indus. Similarly, the villages of Kargil district were inhabited near the Indus and Suru River which ultimately flows in Pakistan.

The survey was conducted in Leh and Kargil district of $\mathrm{J} \& \mathrm{~K}$ to identify traditional water harvesting techniques as well as modern methods. Six villages from Leh district (Skurbuchan, Khaltsi, Domkhar, Gonpa, Stok, Matho) and most of the villages of Kargil district were purposively selected and the investigations were made through multiple field visits, questionnaires and interviews with elderly experienced people regarding the traditional techniques and modern methods of water harvesting.

\section{Results and Discussion}

The details of the present investigation carried out to identify the traditional water harvesting techniques as well as modern methods in high altitude zones of North Western Himalayas is presented hereunder.

\section{Constraints}

There are many problems faced by the inhabitants of cold arid region of Ladakh. However, the main constraints are enlisted here as under:

- Low and erratic rainfall

- Highly permeable sandy terrain

- High evaporative demand

- Deep and generally saline groundwater

- Target oriented development of water resources

- Poor socio-economic condition of local population

- Lack of education

\section{Strategies}

\section{Techniques for Enhancing Runoff from Catchments}

Simple earth smoothing and compaction helps increasing runoff from catchment areas. Success is generally greater on loam or clay loam soils. Care must be taken to reduce the slope and/or the length of slope to lessen runoff velocity and thereby reducing runoff.

Small amounts of sodium salts - particularly $\mathrm{NaCl}, \mathrm{NaHCO} 3$ applied to desert soils where vegetation has been removed- causes dispersion of the surface soil, reducing infiltration and increases runoff. However, this type of treatment requires a minimum amount of expanding clays in the soil.

Removal of stones and boulder and unproductive vegetation from catchment helps in uninterrupted flow, enhances runoff to collection site. Land shaping into roads and collection of water in channels.

Sandy soils have low water holding capacity. Spreading of clay blanket to the soil surface reduces the infiltration and consequently accelerates runoff. Chemical treatments like wax, asphalt, bitumen and bentonite prevent downward movement of water, which augments runoff.

\section{Traditional structure}

Traditional recharge structure practiced in Ladakh is locally known as Zing. These are water harvesting structures found in Ladakh. These are small tanks, in which collects melted glacier water (Sharma and Mir, 2000).

\section{Snow management}

Snow is an important source of water in cold arid regions, and the moisture from it is much more efficiently stored in soil than from rain. 
Nevertheless, the snow resource is not always used to the best advantage because of blowing from fields and snowmelt runoff. With improved catchment, it is possible in some regions that the benefits of one season of snow water could match the soil water accumulation of a year's fallow. Various methods have been devised for retaining snow on the field.

Stubble management: Retaining tall standing stubble after harvest or alternating strips of tall and short stubble.

Snow ridging: Collecting and compacting snow on fields into high ridges or windrows, which then serve to trap drifting snow.

\section{Artificial glacier}

Since times immemorial, the melting water from the glaciers has been the only source of irrigation for 80 percent of the villagers in Ladakh. However, in recent times Ladakhis have observed decreased and untimely snowfall, retreating glaciers which have an impact on water supply both for irrigation purposes and domestic use. This is due changing climate conditions (decreasing precipitation and increasing winter temperature). Winters are getting shorter and with less precipitation and whatever little snowfall is received melt $\mathrm{s}$ away quickly much before it can be put to use in the barley fields in the sowing season.

Besides, due to short summer season they are able to cultivate only one crop per year and this need to be sown in the crucial month of April or May. If it is not sown at this time the crop cannot be fully matured which result in low yielding crops. However, at that time of the year there is not sufficient water in the streams as the natural glaciers are located at a higher altitude and further from the village and this start to melt only in the month of June which is too late for sowing. Keeping the above facts and requirements in mind, locals have devised a unique system of water harvesting/conservation technique to augment water supply for irrigation.

The artificial glaciers have been innovated and located as far as possible closer to the village and at lower altitude so that it starts to melt much earlier as compared to a natural glacier i.e. in the month of April - May so as to supplement with additional irrigation water. During the winter months of November - December, the channel is built which divert/ guide the runoff water to the shady side of the mountain where it can slow down and freeze (Fig. 2).

Figure.1 Artificial glacier introduced by C. Norphel

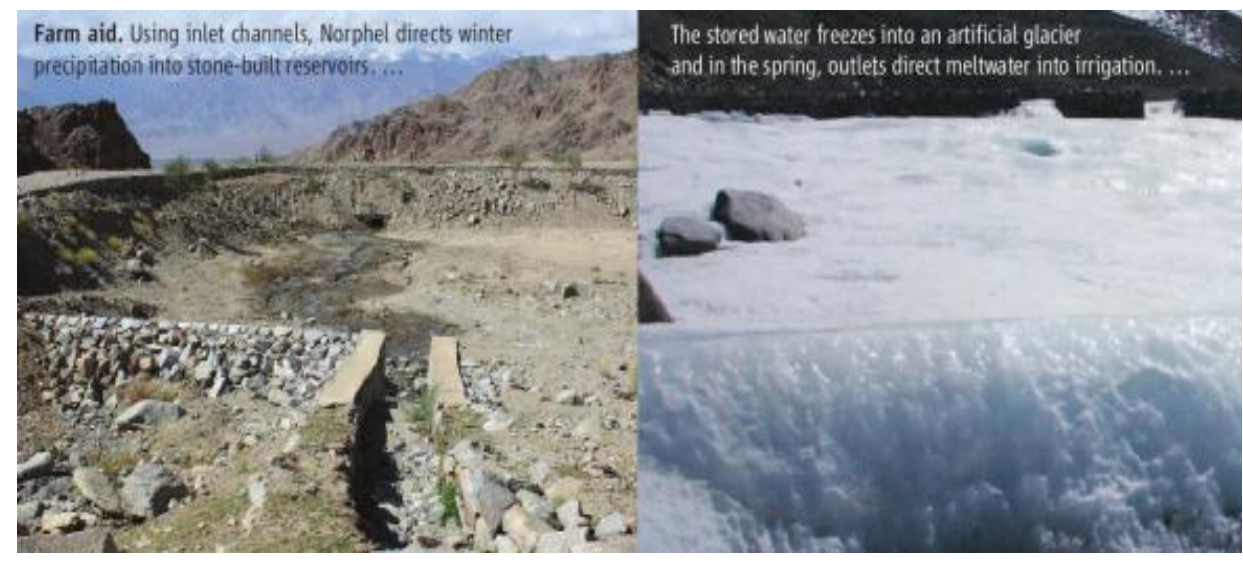

Source: Norphel, 2009 
Figure.2 Drip irrigation system at SKUAST, RARS, Leh

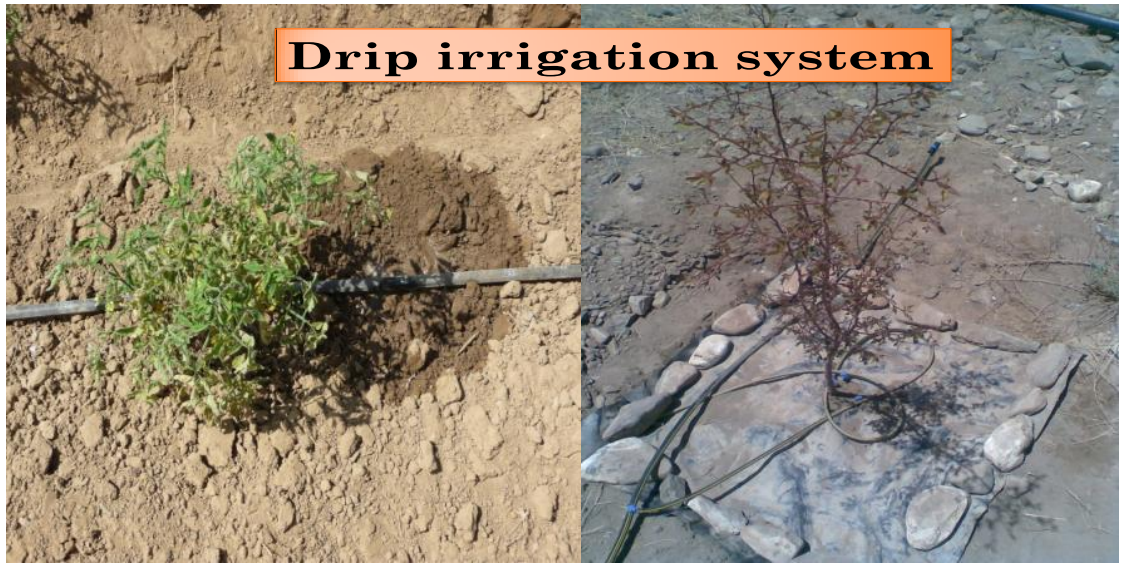

At each dip /slope in the terrain, retaining walls (something like a mini dam) is built which further slows down the water and facilitates the freezing of water in a form of steps, all along the slope into to an "artificial glacier". All efforts are made to tap every drop of water; even the ones flowing below the frozen ice which would add to the surface run off that they are harvestings. This artificial glacier then melt in April and supplies water to the fields of the few villages just in time when the barley need to first water (locally know as Thachus).

\section{Mulching}

In Ladakh, summer season vegetable crops like cucurbits, tomato, brinjal, okra and capsicum etc. are known to respond to mulching by way of early and increased yield (SKUAST, 1996). Black polyethylene 150 gauge thick has been observed very beneficial for the crops like cucurbits, tomato, brinjal, okra, capsicum and chilli (Sharma and Mir, 2000).

In cold arid areas, however, the availability of crop residues for mulch purposes is generally low. In such situations the weeds such as Agropyron repens (Rampa), Chenopodium album (Bathua), Convolvulus arvensis (Tiktikmo), Avena fatua (wild oat) and Setaria glauca could be killed and left over as organic mulch on soil surface (Sharma and Mir, 2000).

\section{Micro-irrigation System}

Micro irrigation, also known as trickle irrigation or drip irrigation or localized irrigation, is an irrigation method that saves water and fertilizer by allowing water to drip slowly to the roots of plants, either onto the soil surface or directly onto the root_zone, through a network of valves, pipes, tubing, and emitters. It is done through narrow tubes that deliver water directly to the base of the plant.

The advantages of drip irrigation are:

- Fertilizer and nutrient loss is minimized due to localized application and reduced leaching.

- Water application efficiency is high.

- Field levelling is not necessary.

- Fields with irregular shapes are easily accommodated.

- Recycled non-potable water can be safely used.

- Moisture within the root zone can be maintained at field capacity. 
- Soil type plays less important role in frequency of irrigation.

- Soil erosion is minimized.

- Weed growth is minimized.

- Water distribution is highly uniform, controlled by output of each nozzle.

- Labour cost is less than other irrigation methods.

- Variation in supply can be regulated by regulating the valves and drippers.

- Fertigation can easily be included with minimal waste of fertilizers.

- Foliage remains dry, reducing the risk of disease.

It can be concluded from the above discussion that the cold desert region of india i,e. ladakh has many constraints such as low and erratic rainfall, highly permeable sandy terrain, deep and generally saline groundwater, high evaporative demand, poor socio-economic condition of local population, lack of education etc. To tackle such problems,the people have to adopt modern water harvesting techniques such as artificial glacier, mulching, drip irrigiation system for efficient use of valuable water resource. Also, more research should be carried out, mainly focusing on moisture conservation in cold desert condition that enables farmers to minimise risks and/ or maximise profits under such harsh climates.

\section{References}

Goyal, R.K. 2010. Rainwater harvesting: A key to survival in hot arid zone of Rajasthan. In K.V. Rao, B. Venkateswarlu, K.L. Sahrawath, S.P. Wani, P.K. Mishra, S. Dixit, K.S. Reddy, M. Kumar and U.S. Saikia (Eds.), Proceedings of national workshop-cum-brain storming on rainwater harvesting and reuse through farm ponds: Experiences, issues and strategies, (pp. 29-38), CRIDA, Hyderabad, India.

Norphel, C. 2009. Artificial Glacier: A High Altitude Cold Desert Water Conservation Technique. Leh Nutrition Project, Leh, Ladakh pp. 15.

Sharma, J.P. and Mir, A.A. 2000. Dynamics of cold arid agriculture. Kalyani publisher, New Delhi, India.

SKUAST. 1996. Research report, SKUAST, RARS, Leh pp. 45.

\section{How to cite this article:}

Phuntsog Tundup, M.A. Wani, Sonam Dawa, Shabber Hussain and Jigmat Laskit. 2017. Water Harvesting and Conservation under Cold Desert Condition of Ladakh (J\&K): Constraints and Strategies. Int.J.Curr.Microbiol.App.Sci. 6(2): 1796-1800. doi: http://dx.doi.org/10.20546/ijcmas.2017.602.201 